\title{
[2]
}

\section{Law and Social Change in Nineteenth-Century Norway}

\author{
Vilhelm Aubert
}

The most cursory inspection of the legal situation in Norway at the beginning of the nineteenth century-and of any modern nation at that time-compared with the situation today reveals great changes. How are we to make sense of these changes? Can they reasonably be termed development or evolution? Do we on closer inspection find amid the changes in specifics also the preservation of some stable traits, a possible nucleus of "the legal"? We are looking for patterns of change, for some order in the myriad changes in details. There are a number of schemes of interpretation and selection of criteria in the more or less "classical" literature on social and/or legal change: from status to contract (Sir Henry Maine), from Gemeinschaft to Gesellschaft (Ferdinand Tönnies), from public law to private law to public law (Karl Renner), from repressive law to restitutive law (Emile Durkheim), and not least, Max Weber's idea of rationalization as a historical trend that also encompasses law.

The scope of this chapter, which is primarily to describe changes rather than explain them, does not permit a thorough exploration of Karl Marx's thesis that law is a superstructure caused by a base of the relationships involved in production. However, the way the law deals with the major cleavages and contradictions in the Norwegian society is a main concern here. In order to see whether it is meaningful to speak about a 
humanitarian trend-a Zug nach Milde, as often claimed with respect to criminal law - the varieties of means of coercion and governance, which play a minor role in the theories mentioned above are the focus here. Because the presentation is limited to the nineteenth century, the origin and development of the welfare state and its interesting legal adjuncts are also outside the scope of this chapter. The period covered is one of preparation for industrialization, a period of intensive nation-building in which Norwegian lawyers took a more prominent part than did lawyers of other European countries.

\section{The "Two Nations"}

From our viewpoint, the two most salient and partly contradictory aspects of the nineteenth century are that Norwegian society was composed of "two nations" but that it was nevertheless conceived of as a "law state" (Rechtsstaat) proclaiming equality before the law. How was this combination possible, how were the inherent iensions dealt with, and what kinds of changes did they trigger? The concept of the "two nations" has been used to emphasize the depth and significance of the gap between social classes, especially with reference to British society in the last century. In Norway it was usual to distinguish between "the common people" (almuen) and "the cultured people" (de kondisjonerte). This conceptualization refers to an agrarian society with a large subsistence sector, and one where the civil servants played a more dominant role than in other European countries at the time. The civil servants (die Beamten) were to a large extent descendants of foreigners, immigrants from Denmark, Germany, Great Britain, France, and other European countries. So although the "two nations" bore considerable resemblance to the division between an upper class and a proletariat, the cultural dimension may have been more prominent than in some other European class societies.

The duality of the Norwegian population was expressed in legal terms in the Constitution of 1814. The constitution was influenced by the American (1776) and the French (1789) declarations of human rights. Although it was based on the theory of the sovereignty of the people, the franchise was limited by a criterion of ownership and education. Because a great number of former tenant farmers had become freeholders during the period preceding 1814, between one-third and one-half of all adult males above the age of twenty-five were eligible to vote in parliamentary 
elections. They were termed the "active" or "real" citizens, and they were more numerous in Norway than in any other European country at the time (J. Seip 1974:42). The allodial rights of inheritance preserved this property structure in agriculture, once gained, but the majority of the rural population constituted tenant farmers, cotters, servants, and laborers. The duality between the "common" people and the "cultured" people was crossed by another-that between men and women. We shall return to this duality.

In spite of what has been stated regarding a basic cleavage in the population, some historians have characterized the nineteenth century as the period of the "law state." The rule of law had been consolidated in the Constitution of 1814, which offered protection against arbitrary government interference in the private spheres of the citizens: no person should be punished or deprived of his property without due process of law. The judiciary was a pivotal institution within this legal ideology. Predictability of, and if necessary defense against, government interference, guaranteed by independent courts, was the main content of the rule of law. The justification for characterizing this society as a "law state" is more formal than real. Most people had few rights to be defended against arbitrary exertion of power, but the few they had were important. Although the penal law was harsh, the common people had a defense against arbitrary arrest. The small freeholders could seek protection of their property rights in fairly incorrupt courts. Even the cotters had some defense against arbitrary evictions, and the servants against untimely dismissal.

The scope of this chapter prevents me from giving a comprehensive picture of the legal development in nineteenth-century Norway. Instead, I choose to analyze the regulation of labor relations and related topics because of the interdependence between the law in this field and the more pervasive aspects of the social structure. In this area the legal rules may appear to be primarily adaptations to changing economic and social conditions, and not so much factors contributing to social change. In certain areas of private and administrative law, the promotional function of legal reforms would have been more prominent.

Criminal law is emphasized because it must be assumed that its function is closely linked to the nature of the state as a means of governance. Changes in the administration of criminal justice must be viewed in the light of changes in the scope and mode of operation in the state apparatus. Again, law as an instrument of social change recedes into the background. Procedural law is chosen because changes in this area 
might be used to test certain widely accepted assumptions about a trend toward higher levels of rationality. Max Weber is the main proponent of this view. Judicial organization and recruitment of personnel, as well as the access to justice, constitute the preconditions for the realization of the rule of the law. It is of interest to study the relationship between this ideal and the actual institutional arrangements.

\section{The Poverty of the State}

In retrospect, poverty is a crucial aspect of the nineteenth century, especially the early nineteenth century. From our point of view it is particularly important to note a consequence of this-the poverty of the state. Early in the nineteenth century, the state budget amounted to no more than a few percent of the gross national product. The national product in its turn amounted to no more than one percent of the gross national product in $1985 .{ }^{1}$ The state budget in 1985 constituted nearly one-half of the gross national product. This change in the scope of state activities, mirrored in the budget, is certainly one of the most momentous political changes to have taken place in modern times. It is a change with obvious implications for the functions of law.

The poverty of the state must have been one reason why the leading jurists of the time so strongly rejected the possibility of using rewards as a means of governance. This theme runs through legal theories in the nineteenth century, not only in Norway but more generally in Europe, even though the poverty of the state was more glaring in Norway than in such countries as England and France. One is bound to ask how the old apparatus could possibly govern? One aspect of the answer is that the state did not to any large extent govern. A subsistence type of social control prevailed. Another answer has to do with sources of legitimacy of a religious, ideological, and national nature. The symbolism of the newly won freedom from the Danish suzerainty, as well as the constitution, were sources of national pride. However, inspection of the allocation of state resources may contribute to an understanding of the mechanisms of governance.

In the period 1821-24, some 40 percent of the annual public revenues were spent on the army and the navy ( 37 percent) and on the administration of justice and the police ( 3 percent). In the period 1851-54, 41

1A quantitative comparison of an industrialized nation and a predominantly agrarian nation can provide only a rough estimate of the scope of the change. 
percent of the state budget was allocated to military expenditures, and 9 percent to the administration of justice and to the police. By the end of the century, military expenditures still accounted for approximately 30 percent of the state budget. We see how the definition of the state as an organization with a monopoly on the legitimate use of force within a given territory is mirrored in the allocation of state resources. This is further emphasized by the source of the state revenues-predominantly customs duties.

Historians have paid little attention to the impact of the military as an institution and a force in Norwegian society, these budget figures notwithstanding. From the point of view of social control, we may assume that conscription and military service had some influence on the recruits, mostly rural youth. It contributed to a sense of national identity, loyalty to the (Norwegian) state and the (Swedish) king. Although most of the youth had some elementary schooling and were literate, the army may have served an educational function, albeit on a minimal level. Military fortresses played an important part in the administration of criminal justice. They were used as prisons for convicts sentenced to "slavery" for more serious crimes. We do not know whether the very presence of the military in the countryside, symbolized by the officers sitting on their farms, had deterrent effects, but we can probably assume that such was the case, even though the military was not (with an exception in 1827) actually used to curb popular unrest.

Although the resources of the state were heavily concentrated on means of coercion, control, and conflict resolution, its power was severely limited. For this reason we find a plethora of what might be termed subsistence social controls and subsistence means of conflict resolution. I am not concerned with the purely informal social pressures and encouragements that exist as all-pervasive elements in any type of social interaction. I am referring to those institutions of control and conflict resolution that are reflected in legislation and that therefore have some kind of public stamp, an authorization by legal rules.

Religion and church as a means of control will not be discussed, although the threat of supernatural sanctions, as well as the promise of eternal bliss, seem to have been universally important mechanisms of social control in all societies that are deficient in means of secular control. It should be mentioned, however, that public confession in church was still in use as a form of chastisement at the beginning of the nineteenth century, authorized by the great codification (Norwegian Law [NL]) of 1687.

The subsistence type of social control is linked to the concept of the 
"two nations" as well as to a patriarchal system of law enforcement. There were those citizens whose behavior and relationships were directly regulated by formal law, and there were those who belonged to a more or less extended household and who were as such supervised and sanctioned by the master.

\section{The Regulation of Labor Relations}

The rule of law demands, in principle, that all penalties inflicted on the citizens be authorized by law: Nulla poena sine lege. However, just as some of the power to tax citizens was farmed out to civil servants, some of the power to punish was delegated to private citizens. According to an old Servants and Vagrants Act, which remained on the books until 1891, the master had the right to chastise his children and servants "with stick or whip, but not with weapons." There could not be any guarantee of equality before this kind of law, which also evidenced the prevalent mixture of family and occupational roles.

In early nineteenth-century Norway the servants constituted the largest single category of the farm population. In 1835 there were 124,600 servants, 103,000 freehold farmers, and 100,000 cotters. In 1825 the proportion of servants was even higher (Steen 1957:59). The relations between the farmer and the cotter, and similarly the conditions of the servant, were based on a contract. Two decrees of 1750 and 1752 stipulated that if the cotter himself had cleared the plot allocated to him, he was entitled to a lifelong contract and the right of his widow to remain. These decrees can be viewed as an early type of labor-protection legislation; they offered some predictability and defense against arbitrary eviction, but no reliable protection against poverty and starvation. The law did not offer a similar kind of protection to cotters who had not themselves cleared the land, although local customs may have done so. The contracts varied between the districts with respect to the amount of obligatory work demanded of the cotter. In some cases it was essentially a labor contract, in other cases it was primarily a tenancy agreement, providing a house for a family, all depending on local ecological and demographic conditions.

The legislation on master and servant relations in force during the nineteenth century did provide servants with some rights. For example, a servant could be served notice only at specified times during the yearly cycle, and it would have to be done twelve weeks in advance of the day 
they were to move, the so-called "days of moving" (faredagene). However, they could be fired at any time for a whole range of more or less diffuse reasons, some of which referred to "immoral" or "indecent" behavior not only within the household but also outside it. In the cities the servants, as members of the master's household, were with few exceptions unable to marry. The legal construction of the servant was academically defined in the Law of Persons, and William Blackstone offered: "The three great relations in private life are 1) That of masters and servants. . . . 2) That of husband and wife. . . 3) That of parent and child" (Blackstone 1809:422). The definition of the servant as a member of the household appears very clearly in the words of a commission appointed by the Department of Justice to prepare a new code around the turn of the century:

It follows from the subordinate position of the servant that it must be at the disposal for the master at any time and has no claim on leisure time during the day, or on holidays, unless this has been explicitly agreed on. Thus, it is not allowed to leave the house without permission, or to overstep the free time permitted. Likewise, the beginning and the termination of the working day is settled by the master, albeit without arbitrarily neglecting local customs. . . . From the position of the servant, it follows, furthermore, that it owes the master obedience-even though the master cannot obtain obedience through the application of force-and is obliged to behave decently and peacefully, as well as comply with the order of the house as determined by the master. (Tyenderetten 1900:11)

Until the middle of the nineteenth century it was against the law for the common rural people to be without employment. To be unemployed was defined as vagrancy and sanctioned by penalties. Similar ordinances existed for some cities, but toward the middle of the nineteenth century these enactments had more or less ceased to function. Still, they are interesting as symptoms of a whole ideology of labor relations and a certain view of class relations.

The Constitution of 1814 was influenced by the American and the French declarations of human rights, according to which all people are born equal. But if there is ever any reason to add George Orwell's supplement- "But some are more equal than others"-it must be in this context, for it is apparent that the laws concerning servants do not deal with them as a category of people who have chosen a particular kind of occupation, but rather as people born into a lower estate, carrying 


\section{Vilhelm Aubert}

with them social characteristics that are almost ethnic in nature. Until 1898 this was also reflected in the franchise that excluded those who "as servants belonged to somebody else's household." Female domestic servants were denied the right to vote until 1913. The rationale for this prolonged exclusion from the electorate was the dependency, the lack of freedom, and the obligations to the master. However, the causes were even more profound; they were based on the idea that the nation consisted of two groups, the "active citizens" and the common people.

The restrictive conception of citizenship is also reflected in the relations between the sexes. Only those who were born male could be equal. Section 50 of the constitution reserved the right to vote for Norwegian citizens alone, without making any exception for women. The same was the case with section 92, concerning the right to hold public office. In 1818 a proposal was presented to Parliament to add to the above clauses "citizens of the male sex," but this was rejected on the grounds that the term "Norwegian citizen," in this particular context, could not conceivably be interpreted as implying women too. Admittance of women to public office again became an issue in 1896. On the basis of the opinion of the Faculty of Law at the University of Oslo, the Justice Department declared that the term "Norwegian citizen" could not be interpreted as comprising women.

To get a more complete picture of class relations in Norway in the early nineteenth century, we must also pay attention to the kind of merchant capitalism that was an important aspect of the economy, although of minor scope. Even though a great deal of mercantilistic regulation had been abolished before 1814, some privileges remained. Merchants in the cities had a monopoly on most kinds of trade-for example, the export of fish and lumber. This legal, and also de facto, monopoly created a dependency relationship between the merchants and clientele of freeholders and independent fishermen. Much exploitation took place, causing considerable unrest and resistance. Gradually, as a concomitant of the new ideology of economic liberalism, the remaining regulations were eliminated.

When these legal monopolies in the fisheries disappeared, the new freedom of trade paved the way for the emergence of local merchants, the so-called "peninsular kings," especially in northern Norway. The relationship of these merchants to their clientele was unregulated by public law, but they frequently had an actual monopoly on all transactions, with the fishermen falling under their sway. In principle, transactions were executed under the general private law of property and 
contract. Although the fishermen were freehold farmers or tenant farmers most of the year, they were dependent on and often heavily indebted to the "peninsular king," who provided them with equipment and food for the seasonal fisheries as well as with necessities of life that the family was unable to produce. In return, the merchant received the catches. The debts might result in the merchant's taking the freehold as collateral while the fisherman-farmer and his family stayed on as tenants. Eviction was rare. The remnants of this "quasi-feudal" relationship could be found up to World War II.

The above descriptions of the servants, cotters, and de facto dependent fishermen-farmers do not exhaust the range of labor relationships in the nineteenth century. Blue-collar and black-coated workers lived in the cities and around some mining centers and large sawmills. Compared with the servants, these workers constituted for the major part of the nineteenth century only a small minority of the working population. Most of the labor relations with such employees were unregulated by public law, with the exception that the situation of the employees of some state-owned mines and works was dealt with in special ordinances-for example, that for Röros Copper Works of September 12, 1818 , which left very little to the choice of the contracting parties.

Toward the end of the nineteenth century, the industrialized sector of the economy had expanded in terms of manpower as well as in terms of its contribution to the national product. In 1890 it was still lagging behind agriculture, including forestry and fishing, as a contributor to the gross national product, 24.3 percent as opposed to 31.6 percent. In 1910 the relationship was reversed to 26.2 percent from industry and 23.7 percent from agriculture. In 1890, as well as in 1910, shipping contributed with between 11 percent and 12 percent to the national product. In 1875 the contribution of shipping had been even greater-13.6 percent.

Aboard ships, paternalistic relations between the skipper and his crew prevailed. In part these relations were sanctified by law, going back to the very detailed regulations contained in the codification (Norwegian Law) of 1687. The ecological and technological conditions of seafaring formed the ship into a total institution that implied that occupational and household roles were mixed, but because the ship's crew was an all-male society, the mix was not the same as in the case of the servants. The very detailed new laws of seafaring of 1860, as well as the revised law of 1893 , testify to the importance the legislators attributed to this sector of the economy. A belief in economic liberalism and in the freedom of contract does not seem to have presented any obstacle to regulations of labor 
relations when such regulation seemed to serve national (export) or other strong interests.

During the last decades of the nineteenth century, Norwegian shipping rose to third in world ranking in terms of tonnage. The law of 1860 contained a number of criminal clauses dealing with disobedience and deviance on the part of the crew. In principle, it also offered crew members protection against a variety of calamities, including brutality and offensive behavior on the part of the skipper. As it were, Norwegian ships at that time offered the crew only half the pay received by British sailors. The low cost of labor, as well as the neglect of safety measures, were important aspects of the formidable financial success of the Norwegian merchant marine.

In industry, however, the legislators were reluctant to interfere. The first piece of legislation, limiting the freedom of contract, referring to factory work, can be dated to an act of 1892 regulating child labor, ninety years after the first British law regarding child labor. In 1915 a law that limited the daily work hours to ten (albeit with many exceptions) was adopted (A. Seip, 1984:120). In principle, freedom of contract was given a much wider scope in industry than in labor relations in agriculture, although all labor relations were based on an agreement between the parties.

In practice, the laborers of both categories were often given no choice but had to take what they got. The contract gave the employer the right to command the worker (Renner 1949:106ff.). In some of the developing industrial regions, paternalism prevailed in the sense that the employer felt a responsibility for the workers and their families, reciprocated by loyalty on the part of the workers. In other regions, such traditions were lacking, and the coercive aspect was so blatant that no belief in the freedom of contract could conceal it. Private law of property and contracts provided a de facto, almost public authority to govern and discipline a work force (although not by violence).

\section{Contracts and Rationality}

Max Weber made a distinction between status contracts and purposive contracts. A status contract is an agreement by which the parties become something in relation to each other that they previously were not. An enduring relationship is created. The parties enter into reciprocal roles for a specified or open-ended period of time. Purposive con- 
tracts do not create roles, but leave the parties as they were, except for the creation of specific rights and obligations. The bonds created by purposive contracts can be ephemeral, as between buyer and seller in a supermarket, but they can also form a long-lasting bond, as between a bank and its customers. An important criterion of distinction is whether the contract implies membership in an organization or group, including the dyad of the married couple. As Weber pointed out, the status contract is normatively derived from household relations and establishes functioning social units. It does more than facilitate exchange, which is the function of the purposive contract.

In nineteenth-century Norwegian society, the contracts between masters and servants, as well as between farmer and cotter, corresponded in important respects to the ideal type of the status contract. In the case of the servant, this was reflected in formal law and in how lawyers interpreted the statutes. The cotter's rights and duties were less specific in the old statutes, and the contracts showed great variations between different districts and regions, as already mentioned. However, the working cotter often found himself in a lasting unequal partnership with the landlord. We must assume that the specific norms regulating this relationship depended on local custom. Whether these should be viewed as customary law or simply as prevailing norms may be a moot point.

The shift from status contracts to contracts closer to the purposive ideal type has been a concomitant to the process of change in Norwegian society from a predominantly agrarian society to an industrialized society. In Weber's terms, the purposive contract represents a higher level of rationality and a later stage in legal development than the status contract does. There is, however, a discrepancy in our material, between the formal aspect of the nineteenth-century legal system and the actual nature of labor relations. Because of the natural, ecological, demographic, and economic conditions, these relationships were to some extent modeled on household relations and on the kind of authority prevailing within the household. The law itself, and the personnel responsible for its enforcement, was quite advanced, however. It is difficult to determine whether, or in what sense, the present-day legal system represents a higher level of rationality.

At this stage it is necessary to distinguish between two kinds of rationality. One, the utilitarian and pragmatic, corresponds closely to Weber's concept of Zweckrationalität-purposive rationality. Within this kind of logic, the task consists of selecting the proper means to 
further a specific goal. The basis for establishing means-ends relationships could be science, technology, economics, or medicine, or it could be common sense, based on personal or group experiences. The other type of rationality has a less certain affiliation with Weber's concept of Wertrationalität-value rationality. Whether or not this concept corresponds to Weber's, the second type of rationality can be characterized by the application of a deductive logic. Choices are made by applying norms to a factual situation and deducing the consequences. This is the logic of the law and "the morality of obligation" in Lon Fuller's interpretation (Fuller 1964:5ff.). The judge finds that a defendant has actually committed an act that corresponds to the description of larceny in the criminal law. He should therefore be punished as stipulated by the same law. This is the kind of reasoning at the heart of decision-making in compliance with law, and it is also the cornerstone of the rule of law.

Although legal reasoning does not in practice exist in pure form, but is interspersed with pragmatic considerations of various types, it is the orientation toward this model that has made the law so useful for conflict resolution and that has also bestowed on it an appearance of certainty and precision. Unlike means-ends reasoning, it does not deal in probabilities, and it seems capable of providing an either/or answer to most questions, regardless of their difficulty. Legal reasoning is thrown as a web, a scheme of interpretation in the hands of lawyers, over a real world of clashing interests and attempts to solve problems in a pragmatic fashion. The predictability offered by the law has to do with the probable reactions in the event a dispute is presented to the courts or subjected to some other legal test. The law sets the constituent rules of the game in the market and establishes the minimum requirements expected of a legitimate participant as creditor, debtor, buyer, seller, employer, employee. But it does not provide certainty with respect to how the market will develop, or for that matter how a marriage will turn out, even if duly contracted according to legal form.

We have no way of knowing whether the status contracts established in nineteenth-century Norway were rational in the sense that they furthered the goals of the parties, or of any one of the parties in an optimal way. They undoubtedly aimed at achieving the goals of survival or wealth and were considered to further these goals in the given circumstances. The natural and social conditions at the time gave scant opportunity for establishing labor relations with, for example, a clear division between household and occupational roles. Although the Ser- 
vants Act did reflect this diffuse situation, it nevertheless specified the obligations of the servant as an employee, and not just as any member of the household.

Written law had already in the beginning of the nineteenth century achieved a high level of formal rationality in terms of codification and the precision of statutes. A corps of well-educated lawyers who played a dominant role in the governance of society had been established. During the eighteenth century, there had been marked progress in legal education and an increase in the requirements for access to the bench and higher positions in the civil service. The judiciary occupied a prestigious role in Norwegian society. In some respects, however, the bureaucracy had not reached the level of rationalization envisioned in Weber's ideal type. Not until the end of the nineteenth century were the last vestiges of the old fee system, which implied some confusion of public and private funds, abolished.

To achieve formal rationality in written law is one thing, to achieve rationality in real social life is another. It is even difficult to find criteria of rationality in social action, one reason being the possible discrepancy between what is good for the actor and what is good for the community. But there are also other sources of this difficulty. If we are to use the concept of rationality, whether in the pragmatic means-ends sense or in the normative deductive sense, it must be conceived of as a procedural concept. It refers to a mode of thinking and decision-making, irrespective of whether it actually leads to truth, justice, or the satisfaction of needs. In spite of the difficulties mentioned, it makes sense to ask questions about the relative and changing preponderance of these two types of approaches to social problems and to planning.

Let us return for a moment to the distinction between status contracts and purposive contracts. It is in the field of consumption that we observe most clearly the increasing predominance of purposive contracts, simply as one aspect of the growing money economy. A subsistence economy does not mean that the individual produces for his or her own individual needs. The basis of subsistence is the farm-often with the additional access to fishing, hunting, woodcutting, and the like. The produce of the farm also supported the servants, sometimes a pauper, and the parents of the farmer would be given what they needed for their livelihood-a house, food, firewood, and so on. This subsistence type of pension right was a burden on the farm itself; it could not be bought or sold. Barter between neighbors on the basis of reciprocity served as a means of 
exchange without any monetary intermediary. In the subsistence economy, consumption rights depend partly on ascribed kinship status and partly on the status contracts of marriage and of service.

I have emphasized the legal ordering of the relations between social classes in the nineteenth century. In the references to the Servants Act, the relationship to vagrancy was mentioned. Possibly because of the scarcity of state resources, the emphasis on coercion was predominant in the upper-class view of the common people. In what follows, we shall look at the development of the criminal law.

\section{Criminal Law}

The main legal basis for administration of criminal justice at the beginning of the nineteenth century was the Norwegian Law of 1687, and a royal decree of 1789 on theft. On the one hand, the 1687 law reflects the poverty of the state in the sense that the sanctions prescribed are to a large extent corporal punishments-whipping, mutilations, branding, and pillorying, as well as the death penalty. These are inexpensive sanctions. So also were the public degradation ceremonies, such as confession and chastisement in church. Fines and the loss of property were prescribed punishments for a number of delinquencies. Insofar as such punishments as deportation to the fishing outposts in the north, workhouse assignment, or slavery in military fortresses were implemented, it was done with a view to production.

A subsistence type of legal control is also made apparent in the extent to which the policing, prosecution, and executive powers were left to the master of the household or to the victim of the offense. "Private penalties" was a common term. Fines should be paid to the victim or the master, either as restitution or as a fee for the contribution to maintenance of law and order. The class aspect is glaringly apparent. One estate was authorized by law to discipline another.

The development from private penalties as prescribed by the Law of 1687 , to the system of exclusively public penalties that emerged in the nineteenth century, appears to contradict Durkheim's thesis concerning progression from repressive to restitutionary law (on this point, see Lukes and Scull 1983:14). Durkheim seems to have ignored the significance of the increasing wealth of the state for the forms of legal control. It should also be noted that while the legal text delegated punitive power to private citizens, in Norway the provincial governor himself had to do much of the prosecutorial work. The law was modeled on conditions in 
Denmark, where a manorial system was widespread. Manors existed in only five districts in Norway, where the landlord was equipped with judicial power, the birkerett. In most parts of the country, however, there were no lords of the manor to carry out prosecutorial and judicial power.

The penal system was cruel. Theft and infanticide were in most cases met with a death sentence. However, a characteristic trait of the system around the turn of the eighteenth century was the frequency of royal pardon. Mercy, as well as privileges, were important aspects of governance by the grace of the monarch. This aspect of the system can be contrasted with Weber's concept of formal legal rationality. It was a symptom of the prevalence of traditional authority mixed with the charisma of the king. It was fuel to the popular conception in Norway that the Danish king, and later to some extent the Swedish king, was a good father, certainly better than his unpopular underlings—-the bailiffs and tax collectors.

During the period 1815-40 the number of prisoners increased by a factor of between 2 and 3 relative to the size of the population. The majority of these, sentenced as recidivists or for grave crimes, were kept in chains, in "slavery," in military fortresses. Women and other delinquents were kept in penitentiaries or workhouses. Women constituted about one-fifth of the prison population, a larger proportion than today. The great increase in the prison population reflected some increase in the crime rate, but probably even more the substitution of imprisonment for corporal punishment and the death penalty. An act of 1815 abolished most corporal penalties other than whipping.

There was a growing awareness in leading circles that the prisons were in abominable condition and that the situation of the inmates was unacceptable. There had been no construction of new prisons to accommodate the quadrupling of inmates. After a prolonged period of preparation, a new criminal code was issued in 1842 . This was another step in the direction of milder penalties, although convicts sentenced for the gravest crimes were regularly kept in chains until 1872 (Sandvik 1980: 93ff.). Up to the time of the new criminal code, imprisonment had been viewed either as a special kind of corporal punishment or as forced labor. With the revision of the criminal law, the main emphasis was on correction. A new central penitentiary was constructed on the model of the Philadelphia system, a main feature of which was that the inmates spend time in isolation and have ample opportunity to ponder and repent their misdeeds. 


\section{Vilhelm Aubert}

The criminal code of 1842 was harsh but extremely systematic, thus corresponding to the procedural ideal of the rule of law. Its discrimination against the poor is apparent in clauses 12 and 13, on theft in the forest: "Unauthorized removal of leaves or evergreen branches from trees in the forest, or of pieces of trees that have been felled by wind or that have dried, and which have not already been visibly brought together by somebody else, should be punished by a fine of from 60 shillings to 20 dollars." If the pieces of wood appeared in a heap, the offense might still be subsumed under this mild clause if it was a question of firewood (Schweigaard 1883, Vol.2:439). In other cases, removal of the wood was considered theft and met with more severe penalties. One is struck by the similarity between this clause in the Norwegian penal code and the corresponding clause in the German law, so scathingly attacked in Marx's famous article of 1842, "Debatten über das Holzdiebstahlgesetz" (Marx and Engels 1970:109ff.).

From the 1840s to the end of the century, there was a steady decline in the number of prisoners, but one does not find a corresponding decrease in the relative number of individuals convicted of delinquencies (Christie 1975:242-246). The increasing use of suspended sentences and fines may account for some of the discrepancy, which has not, however, been fully explained in the criminology literature.

A revision of the criminal code in 1874 reduced the penalties for a number of crimes and increased the options available to the court with respect to the kind of sanction inflicted. The "Act on the Limitation of the Infliction of Corporal Chastisement" of 1891 should also be mentioned in this context. It reflects an amelioration of the patriarchal system, inside and outside the family, embedded in the Norwegian Law of 1687 , even though the practical consequences may have been modest. The act deprived the master of the household-as well as the superintendents of some public institutions, and skippers and craftsmen-of some, but not all, of their power to ensure discipline by physical means. The act represented a further step in the state's appropriation of the monopoly on the lawful use of force.

\section{Penalties or Welfare?}

The last decades of the nineteenth century were characterized by new concepts of crime and punishment that were strongly influenced by continental, especially German, criminological theories. The reformist 
zeal must also be viewed in the light of considerable turbulence in the economic, demographic, and political fields. Ministerial responsibility to Parliament was introduced in 1884 , after an unusually divisive political contest. At the same time, the first regular political parties were established-the Labour Party in 1887. The first strikes occurred. Emigration to the United States took on great proportions, as did migration from the countryside to the cities. Shipping became a major industry. Industrialization was on its way. The union with Sweden approached dissolution, which finally occurred in 1905. A rapid extension of the franchise took place.

One might condense all these changes into the words "rapid modernization." Modern attitudes toward the treatment of deviance were expressed in a new emphasis on social policy and treatment. I shall mention only two examples of this. The new criminal code of 1902, still the major source of criminal law, will not be dealt with here. However, two years earlier, in 1900, Parliament passed the Act on Vagrancy, Begging, and Drunkenness. There was no longer any question of dealing with servants and vagrants in the same statute. A process of legal differentiation had taken place, corresponding to a shift in the nature of labor relations and a reduction in the social gap between employers and employees.

The Vagrancy Act authorized the courts to sentence drunkards to long and often indefinite terms of forced labor in prisonlike workhouses for repeated but minor misdemeanors. The Poor Law had for a long time contained a clause authorizing police to place vagrants in workhouses for periods of up to six months without due process of law. From the point of view of the rule of law in a purely formal sense, the Act of 1900 represented an advance. In other respects, it represented a step backward, especially because of the pronounced and unjust asymmetry between the offense-appearing repeatedly drunk in public places-and the very long terms of forced labor in an unpleasant environment. The law was not revised until 1970 (see Christie 1960).

The prominent jurists who fathered the Vagrancy Act of 1900 justified the new law in the most modern and humanitarian language as establishing a system of treatment and correction. Drunkenness was construed as a condition analogous to illness, in need of cure rather than punishment. A cure should last until the illness disappears, which in the case of many alcoholics may be a very long time. This new ideological construction of the drunkard reduced legal justice and equality before the law to secondary considerations. Proponents of the Vagrancy Act did not argue 
that extended deprivation of the freedom of alcoholics might protect their wives and children from brutality and abuse, and critics of the vagrancy law have not paid attention to this aspect of the law. It is interesting to note that this argument would have gained considerable support in recent years, even if it could not have saved the Act of 1900 .

The second example taken from the reform period in the last decades of the nineteenth century is the "Act on Treatment of Neglected Children," drafted in 1900 (Dahl 1985:94ff.). This act established child welfare boards charged with a number of tasks and authorized to use various measures vis-à-vis children who presented serious problems, ranging from juvenile delinquency to neglect or abuse on the part of their parents. One measure available to the child welfare boards was placement in a "school house" or reformatory school. Such placement, even when caused by delinquency, was not intended to be a form of punishment. Reports from the twentieth century emphasize the penal nature of these "schools." Just as in the case of vagrancy and drunkenness, a socially felt need to remove individuals from their previous social environment was combined with a benevolent and humanitarian ideology. The foreign influences derived from the same sources and were mediated by some of the same national key figures. The justification for sidestepping courts and implementing involuntary institutionalization as a means of correction was the necessity to raise and educate minors. The houses of correction were construed as schools or even homes. The stringencies of the rule of law were apparently not applicable, because it was a question of providing the children with new resources, not of depriving them of anything. From now on child-saving should be a government responsibility, not left to private philanthrophy.

There is an inherent tension between the rule of law and legal reasoning, on the one hand, and the optimal pursuit of goals with the most effective means, on the other. The theory that provided legitimation for the new correctional measures has been termed "positivism." The new criminology was undoubtedly influenced by the success of the natural sciences as the fundament of industrialization. A belief in social engineering arose, founded on the adoption of a purposive rationality that tended to reduce the significance of the deductive and normative rationality of the law.

Theories seldom leave lasting results, unless they can be used to further the interests of concerned groups with some power to influence events. In this case, the ideological trend was grasped by two profes- 
sional groups that were dissatisfied with conditions in the fields of their immediate concern. Many criminal lawyers, particularly those associated with the prison system, disliked the practice of putting wayward children in prison. They were troubled by the plight of these children and were concerned about the kind of influences they were exposed to in prison. They wanted children removed from prisons and responsibility for them transferred to other agencies.

The leading teachers and educators had a different problem. They were about to reform the elementary school system through a unification that would bring all pupils, regardless of social-class background, into the same classroom. The new Elementary School Act of 1889 went a long way in this direction. To make the new unified school system generally palatable to the bourgeoisie in the cities, it seemed appropriate to assure those in need of assurance that their "good" children would not be contaminated by the presence of "bad" working-class pupils. Ideologically, the reformatory schools administered by the child welfare boards in the best interests of the children themselves served as a guarantee that the regular school system would not be burdened with the presence of wayward or neglected children. The common interest of criminal lawyers and educators became an important force behind the establishment of reformatory schools. It must, of course, be viewed not only in the light of the general "positivist" trends of the day, but also with the urbanization and concomitant uprootedness of certain sections of the large cities in mind. Quite generally, registered criminality, then as now, was predominantly an urban phenomenon.

The great reforms in criminal law toward the end of the last century pose interesting problems concerning the relationship between law and ideology, and the changing social and economic structure. First, legal change cannot be fully understood by reading the arguments in the preparatory reports preceding the passing of a new enactment. The reasons given and the theories on which they rest must often be seen as legitimation for the achievement of other goals and for the furtherance of interests that are not clearly expressed. The second result, related to the first, is that there will often be a discrepancy between the law on the books and the law in action. This does not mean that such laws, although they may fail in relation to their stated goals, are inconsequential. The legal reforms around the turn of the century set the stage for the more profound reforms initiated, although not finally solved, by the emergence of the welfare state. 


\section{Procedural Law}

An inspection of changes in legal procedures might be a suitable testing ground for theories assuming a progressive rationalization of law over time. We will consider criminal law and civil procedural law separately. As mentioned previously, some of the criminal procedure in the eighteenth century was left in the hands of private citizens, but in Norway the provincial governor (amtmann) was left with most of the prosecutorial tasks. He had at the time a wide variety of administrative functions as the local representative of the royal power (Holme 1985), which meant that there was no specialized prosecutorial branch of the government. It also implied that the Ministry of Justice could instruct in matters pertaining to prosecution. From the point of view of the rule of law, it meant that the potential defendant's protection against state power was weaker than it later became.

Another weakness is expressed in a law passed in 1827. Before that year, defendants had the right to defense counsel paid out of public funds. The Act of 1827 introduced an officer of the court called a "reporter," who was charged with detailed preparation of the trial and served as a mixture of prosecutor and defense counsel. The law assumed that the reporter's function would be carried out primarily by bailiffs and sheriffs. The defendant could still hire legal counsel at his own expense, which in practice severely limited this custom. The judge himself also had considerable responsibility for preparing the indictment.

The procedure was inquisitorial. In terms of the rule of law, this is clearly a flaw, but as measured against criteria of rationality, the matter is more complicated and the answer not so certain. As a means of bureaucratic processing, the inquisitorial procedure may be more efficient than leaving the matter to an adversary process, where each of the two contending parties present their own and misleading version of facts and rules. On the other hand, it could be claimed that a sharp division of prosecution, judgment, and defense corresponds to an ideal of specialization of tasks. We gain more understanding by looking on the later change from an inquisitorial to an adversary type of process as a shift in the distribution of power instead of as a change in the degree of rationality.

Political circles soon came to realize that the criminal procedure corresponded poorly to the ideal of the rule of law as expressed in the Constitution of 1814. It did not compare favorably with the judicial systems in countries functioning as models for Norwegian lawyers ei- 
ther. An interest in the jury system arose, as did interest in the adversary process and the specialization and independence of the prosecutorial office. However, the period of gestation for a new general procedural code was extremely long. The new principles of trial by jury as well as a separation of prosecutorial tasks from the general administrative office of the provincial government were not introduced until 1887. Already in 1866 the office of the "reporter" had been divided into two-a prosecutor and a defense counsel. The Act of 1866 had also made it obligatory to specify the indictment in detail.

The changes prescribed by the Act of 1887 are ambiguous in terms of rationality. The establishment of a separate prosecutorial branch of the government that could receive instructions only from the cabinet, not the Ministry of Justice, could well be viewed as an element in the general move toward a higher degree of functional specificity in public administration. But the jury system represents a departure from the move toward a more specialized bureaucratic organization based on experts. Whatever the consequences were, and they were certainly not revolutionary, introduction of the jury was regarded as a political victory for the democratic forces. It was assumed that the jury system deprived the leading strata of civil servants and lawyers of some of their power by transferring it to the people. From the point of view of societal integration, it may well be that the jury represented some kind of rationality, but not the kind one usually has in mind when discussing the running of organizations, firms, and bureaucracies.

The principle of lay judges had a long historical tradition, broken by the Norwegian Law of 1687. In civil and criminal cases, the court was reduced to the single professional judge appointed by the absolute monarch. There were exceptions to this general rule, insofar as eight lay jurors participated in litigation over allodial or property rights, as well as in cases concerning life or honor. The establishment of the jury system and lay judges in the district courts in the Act of 1887 had a more immediate predecessor in the 1860 Act of Seafaring. The latter act established maritime courts composed of the district judge and two laymen with experience in seafaring and shipping. This served as a model for the later introduction into the court system of experts on a variety of issues.

The extremely prolonged preparation of the Criminal Procedure Act of 1887 invites a few remarks on time and the law. While the waiting period may have been unusually extensive, it is a fairly common feature for legislative projects that raise matters of principle. This often results 
in proposals being discarded after they have received considerable public attention, and it constitutes an important ingredient in the symbolic function of law. While the old and unpopular law is still in force, those who dislike it are to some extent pacified by the promise of better times. In principle, it is admitted that there may be due cause for their grievances and that it is only a matter of time before the situation will be corrected. However, as the popular saying goes, "While the grass grows, the cow dies."

Up to the end of the eighteenth century there had been a continuous professionalization of the judiciary. By then the judges had become welleducated jurists, but they were still only partly on a regular salary. For the remainder, they had to extract their income from fees paid for their offices by the population. Some districts were fat, others were lean. Because the regular salary was derived from a tax on the farms in the form of the tithe, this too varied with the wealth of the district. There was no clear separation of private funds and public funds-and in Weber's terms this was a flaw in relation to the ideal typical model of a bureaucratic office. One might also view this situation as an example of a subsistence type of social control. According to the Act on Remuneration of 1872, judges and bailiffs were to receive fixed salaries from the state. From then on, public funds were separated from private funds.

Around the turn of the eighteenth century a new element was introduced in civil litigation. From then on, the board of conciliation served as obligatory first instance in civil suits. An act of 1824 confirms and specifies in great detail the procedural rules pertaining to this new institution, which has survived to the present day. Conciliation boards were composed of two lay counselors, whose task was to mediate between the contending parties and to seek a solution by consent. Until 1866 these boards had no authority to pass a verdict. The establishment of the boards of conciliation can be viewed as another symptom of the poverty of the state in a country with an extremely dispersed settlement of the population. The judges would have been unable to reach the clientele, and vice versa, without incurring exorbitant costs to be paid by the clientele.

The institution seems to have been very popular, and it taught a large number of board members a great deal about the law. There is, however, an interesting contrast between the detailed formality of the code itself and, as we must assume, the informality of the proceedings. From one point of view, the detailed code notwithstanding, the establishment and extensive use of conciliation boards appears to contradict a trend in legal development toward ever higher levels of rationality. It introduces 
a new lay element at a crucial stage in the administration of justice. Although the 1824 code contains eighty-six sections, it leaves great discretionary powers to the boards in their administration of the proceedings. It should also be noted that the conciliation boards served as miniature legal academies and thus served to spread at least some rudiments of legal thinking among broad strata of the population.

The boards of conciliation were established by royal decrees of 1795 and 1797 according to French models, with the intention of reducing litigation. Statistics show an increase in cases dealt with by these boards, from 12,759 in 1814 to 64,685 in 1827 . From 1827 to 1849 there were ups and downs, with a peak of 86,376 in 1838 . In around 60 percent of the cases, an agreement between the parties was reached or the case was terminated because the plaintiff was absent. As it turned out, only one in ten cases was appealed to the courts. Thus, the intention of reducing litigation was fulfilled, although some of the complaints brought before the boards of conciliation might not have led to a suit even if the boards had not existed (Röer 1978).

In 1866 an amendment to the Law of 1824 authorized the boards of conciliation to pass judgment in minor debt cases, numerically a very bulky part of the caseload. Today the boards function largely as smallclaims courts. In 1972, some 52 percent of all cases before them were terminated with a verdict in the absence of the defendant, usually concerning a debt. Only 7 percent of the parties were reconciled in front of the board. In family matters, appearance before the board is usually no more than an empty formality, a necessary condition for bringing a lawsuit for separation or divorce (Aubert 1976:195).

\section{Concluding Remarks}

I began by referring to some well-known theoretical approaches to legal change. It turns out, however, to be difficult to present a historical narrative based on a certain respect for factual "details" and couched in theoretical language. The theories serve a useful function by suggesting what one should look for, but they can also function as blindfolds if the historical material is treated solely as a testing-ground for theoretical assumptions. There is such a thing as letting the data speak for themselves, even if their presentation throws doubt on the relevance of concepts and classifications respectfully adopted from the theoretical literature.

The preceding presentation puts great emphasis on the nature of the 
state, not just on the legal system as such. The impulse to consider the wealth or poverty of the state as a particularly significant aspect of governance is derived from work with the legal system of the postwar welfare state. The welfare state exerts most of its control through its distribution of material resources-above all, money. This raises the question of whether large sections of modern welfare and related legislation establish a legal system based on rewards rather than on "commands backed by force."

In the material presented, one can perceive an ideological move away from the very harsh and very comprehensive penal system, a system that to some extent delegated punitive powers to private citizens. It was from the beginning an inexpensive system, gradually to be supplanted by a system demanding more resources from the state. The only great scholar who dealt at some length with the problems of sanctions and who included rewards was Jeremy Bentham (1962:192-265). His views on rewards in relation to law are somewhat contradictory, or at least enigmatic, and they are also largely unknown. It must remain for another occasion to investigate the relevance of his analysis to the task of describing and explaining legal development.

The historical material reflects relatively clearly the salient features of the basic cleavages in the Norwegian society of the nineteenth century, as well as some changes in the economy and the class structure. These changes would be more pronounced, of course, were we to follow the trend into the twentieth century and up to the present day. The description of legal change is fragmentary. If space had permitted, it would have been highly appropriate to deal here with changes in social legislationthe development of what has been termed the "social assistance state" (Seip 1984) and to follow the development to the welfare state.

The legal changes described in this chapter must be viewed as responses to changing social and economic conditions, but that does not mean they are linked to structural changes by strict causality. The legislators' interpretation of the social conditions is also influenced by other factors, not least by more general European ideological currents. It is therefore often a moot point whether the legal development is optimally adapted to the demands of the economy or to the interests of the groups that hold the power to issue laws. The initial poverty of the state, as well as the gradual increase of the wealth of the state, have been decisive economic factors.

Another significant question is whether the legal texts and efforts described above have, in their turn, influenced the course of events. Because the notion of planning through law had fallen out of favor during 
the dismantling of the old legal privileges, and because the state remained relatively poor throughout the nineteenth century, it is difficult to find concrete traces of such influences. We might have seen more of it had we studied, for example, the changes in company law or patent law. However, we are led to assume that the very existence of a fairly well developed legal system, a corps of relatively uncorrupt civil servants, and a growing legal profession contributed to the kind of trust that is conducive to economic growth. It is to be expected that a comparison of the legal developments of the nineteenth and twentieth centuries would reveal a change. The ideology of economic and welfare planning, supported by the new power of the labor movement, especially in the period after 1945, presents the problem of law as a driving social force in a new light.

What does the historical material show about rationality and development? Above all, it illustrates the difficulties involved in the very use of rationality as a yardstick for legal systems. In terms of form, the legal texts do not exhibit clear-cut changes. Modes of conflict resolution may have varied, but not according to a unilinear trend toward ever higher levels of formal legal rationality. Toward the end of the century, the courts were given more discretion in the choice of penalties. This could be seen as a reduction in the kind of rationality that rests on deductive logic while at the same time representing an increase in terms of purposive rationality. The same trend might be found in the legislative debates and reports, with the greater emphasis on pragmatic considerations. How should one select means-based on what was assumed to be scientifically established - to further the goals of education, treatment, and deterrence? The spirit of future-oriented planning was entering the legal arena with renewed strength.

\section{Acknowledgments}

I thank Susan Powers, of the Institute of Sociology, University of Oslo, for her assistance in improving my English.

\section{REFERENCES}

Aubert, Vilhelm. 1976. Rettens sosiale funksjon. Oslo.

Bentham, Jeremy. 1962. "The Rationale of Reward." In The Works of Jeremy Bentham, vol. 2, New York. Reproduced from the John Bowring edition of 183843. 


\section{Vilhelm Aubert}

Blackstone, William. 1809. Commentaries on the Laws of England, vol. 1, chap. 14. 15th ed. London. First edition 1765.

Christie, Nils. 1960. Tvangsarbeid og alkoholbruk. Oslo.

- 1975. Hvor tett et samfunn. Oslo.

Dahl, Tove Stang. 1985. Child Welfare and Social Defence. Oslo.

Fuller, Lon. 1964. The Morality of Law. New Haven.

Holme, Jörn. 1985. Fra amtmann til statsadvokat. Oslo.

Lukes, Steven, and Andrew Skull, eds. 1983. Durkheim and the Law. Oxford.

Marx, Karl, and Friedrich Engels. 1970. Werke, vol. 1. Berlin.

Renner, Karl. 1949. The Institutions of Private Law and Their Social Functions. London.

Röer, Inge-Lise. 1978. "En reform med varig virkning? Forlikskommisjonene i deres første tid." Mimeographed term paper on file with the Institute of Private Law, Faculty of Law, University of Oslo.

Sandvik, Gudmund. 1980. “Lov, dom og straff." In Norges kulturhistorie 5. Oslo. Schweigaard, Anton Martin. 1883. Commentar over Den norske Criminallov, vol. 2. Kristiania.

Seip, Anne Lise. 1984. Sosialhjelpstaten blir til. Oslo.

Seip, Jens Arup. 1974. Utsikt over Norges historie, vol. 1. Oslo.

Steen, Sverre. 1957. Det gamle samfunn. Oslo.

Tyenderetten efter norsk og fremmed lovgivning [The law of servants according to Norwegian and foreign law]. 1900. Kristiania. 